\title{
Antônio Vieira e a consciência do jogo: os mundos retórico e ontológico na gênese do período Barroco
}

\author{
Artur Almeida de Ataíde \\ (Universidade Federal de Pernambuco)
}

\section{RESUMO}

Tomando por ponto de partida alguns trechos do Sermão da Sexagésima, do Pe. Antônio Vieira, o presente estudo examina que papel pode ter tido o desenvolvimento da retórica, na época barroca, para o estabelecimento de uma linguagem sempre em vias de fazer ruir as visões substancialistas do mundo. Com base em alguns paralelos imprevistos, como sugerem os nomes de Homero, Píndaro e Torquato Tasso, argumenta-se que a tensão entre mundo retórico e mundo ontológico será tão decisiva para a compreensão do barroco quanto a tensão entre o terreno e o divino.

PALAVRAS-CHAVE: barroco; retórica; Pe. António Vieira

\section{ABSTRACT}

Taking as a starting point some excerpts from the Sermão da Sexagésima, by Fr. António Vieira, this paper investigates what role the development of rhetorics in the Baroque period might have played in the articulation of a new language pattern, always about to dismantle substancialist views about the world. Based upon some unexpected paralells, as the sole names of Homer, Pindar and Torquato Tasso may suggest, it is argued that the tension between rhetorical world and ontological world is so decisive for understanding Baroque as the tension between the earthly and the divine.

KEYWORDS: Baroque; rhetorics; Fr. António Vieira 
Costuma-se apontar, na gênese do que foi o período barroco, o conflito entre dois grandes, digamos, complexos culturais. O primeiro seria a visão de mundo que se vê florescer com a expansão marítimo-comercial, desdobrada em ramificações inúmeras, de caráter tanto técnico, quanto ético e estético. Entre elas, poderíamos listar: certa reabilitação do mundo sensível, do testemunho do real via cinco sentidos, que, em literatura, já encontra exemplo palpável no Inferno da Commedia, de Dante; o humanismo, e a maior abertura do pensamento para os fatos terrenais, mais terrenalmente analisados, como no exemplo de Maquiavel; o desenvolvimento paralelo das ciências naturais, signo maior do desprendimento de então nas relações com o mundo, cujas engrenagens divinas vão aos poucos se deixando revelar - como o corpo humano sob os olhos de Da Vinci - a olhos que não os de Deus. O segundo complexo poderia ser visto como uma espécie de refluxo dessa primeira liberdade, e englobaria, como marco, o concílio de Trento, ocorrido entre 1545 e 1563, desencadeador da Contra-Reforma, e o absolutismo monárquico, golpe definitivo contra qualquer aspiração a um regime político mais aberto e, conforme desejaria o racionalismo crítico do século, mais atento às liberdades individuais. A partir da tensão entre esses dois complexos é que a "diafaneidade do Quinhentos" (ÁVILA, 1971, p. 33), uma linguagem supostamente obediente às coisas, uma linguagem "natural", no sentido camoniano, daria lugar a uma forma advertidamente transfiguradora do real:

A linguagem antes de âmbito denotativo da renascença reflui então às simbologias de fundo religioso e mitológico, recobrindo de metáforas e claro-escuros o mundo em representação. As manchas pictóricas e o dinamismo escultórico, tanto quanto a reverberação sinestésica da imagem literária, envolvem de uma nova fantasia formal o núcleo da mensagem ou do pretexto barrocos, refugindo com isso o criador ao compromisso declarado de objetividade com o real (ÁVILA, 1971, p. 34).

Ainda segundo Ávila (1972, p. 35), a exploração tipicamente barroca das potencialidades da língua seria como que o último reduto de uma liberdade individual sufocada: o artista barroco, em face do absolutismo político e religioso, reservaria o espaço autônomo da arte para o exercício de sua própria soberania como "criador de formas"; a hipertrofia do artifício, assim, não faria transbordar do poema apenas figuras, cores, sons e texturas, mas também "uma aspiração à liberdade individual frente às forças do contexto". Embora esse fundo ideológico libertário possa sugerir algum tipo de continuidade ética entre o humanismo e o barroco, claro está que de nada, ou de muito pouco, ela terá valido para manter a salvo da nova obscuridade o calmo hedonismo horaciano da renascença. O barroco, afinal, seria

o espaço agônico entre a materialidade transitória das coisas e a transcendente perenidade do espírito, espaço que a arte barroquista procura dimensionar nas seis faces de um dado cujo lance é sempre o jogo consciente da forma, da cor, da palavra, da idéia, do ritmo, da melodia (ÁVILA, 1971, p. 35).

Assim, ainda que resumidamente, parecem se esclarecer as tensões históricas de que a linguagem barroca terá se alimentado. Uma questão, no 
entanto, talvez permaneça em aberto. Vemos uma linguagem de contornos firmes e sólida — não obstante leve —, como a do renascimento, trocar a substancialidade do mundo pelo que será a grande incursão barroca nas virtualidades da língua, trazendo à tona, com uma sobreposição tantas vezes vertiginosa de metáforas, sons e jogo lógico, a mobilidade inapreensível de formas ilusórias a que o discurso, em prosa ou em verso, pode se reduzir. Até que ponto, pois, a tensão inegável entre os nossos dois complexos nos servirá de base suficiente para que entendamos esse aspecto preciso da transformação? O Sermão da Sexagésima talvez nos dê a pista de um terceiro termo, tão indispensável quanto os outros dois, para a caracterização do mundo cultural barroco. Passemos antes, no entanto, por uma curta digressão teórica e histórica.

Nos primeiros capítulos de Mimesis e modernidade: formas das sombras, Luiz Costa Lima explica a importância do que chama a "dobra" da palavra para a existência do conceito de mímesis. No período que abrange o micênico e a Idade Arcaica gregos (até fins do séc. VI a. C.), ao fim do qual o pensamento filosófico começará a se desenvolver, as relações entre linguagem e mundo na cultura grega terão sido bastante particulares, segundo esclarece o teórico, citando Marcel Detienne:

Mnemosyne é a viga-mestra da indagação da verdade. Daí a importância do poeta: "Por sua memória, o poeta tem acesso direto, em uma visão pessoal, aos acontecimentos que evoca; tem o privilégio de entrar em contato com o outro mundo. Sua memória lhe permite "decifrar o invisível". A memória não é portanto apenas o suporte material da palavra cantada, a função psicológica que sustenta a técnica formular, é também sobretudo a potência religiosa que confere ao verbo poético seu estatuto mágicoreligioso. Com efeito, a palavra cantada, pronunciada por um poeta dotado de um dom de vidência, é uma palavra eficaz; por sua virtude própria, ela institui um mundo simbólico-religioso que é o próprio real" (LIMA, 2003, p. 32).

Citando novamente Detienne, completa em seguida: “a palavra é verdadeiramente concebida como uma realidade natural, como parte da physis" (LIMA, 2003, p. 33). Dito de outro modo, é precisamente a "dobra" da palavra o que, no período histórico mencionado, parece inexistir: é que a voz da memória, ou seja, a voz divina que se faz ouvir através do poeta, será, por si só, a verdade ela mesma. A necessidade de análise lógica ou de pesquisa hermenêutica em busca do sentido verdadeiro das coisas terá sido uma atitude imprevista pela própria prática social vigente: a narrativa mítica poria os ouvintes em contato imediato com uma estrutura de sentido incontroversa subjacente ao mundo, como sua ordem última, sua verdade; tanto quanto esta, a narração do aedo não seria problematizável: sua palavra é irmã do real. Devemos ter em conta que, nesse caso, tratamos de um contexto cultural em que o mundo simbólico da cultura e o mundo como existência autônoma; o mundo das subjetividades e o mundo objetivo; ou, ainda, nas palavras de Schiller ([s./d.]), o "ideal" e o "natural", não constituiriam dois planos distintos do real; a indistinção entre humano e extra-humano seria, precisamente, o que tornaria não apenas possível, mas o que tornaria talvez inescapável, que os mestres da cultura, da memória e da língua — os próprios aedos — viessem a ser também, indissociavelmente, os "mestres da verdade", 
conforme a expressão de Detienne.

Terá sido ainda no mundo grego, no entanto, que as relações entre cultura e verdade se terão alterado. É provável que já Anaximandro, por exemplo, tenha mantido alguma reserva em relação aos mitos, relativizando a sua verdade, ainda que o uso efetivo, para designar pejorativamente o fantasioso em oposição ao verídico, de um adjetivo derivado da palavra mýthos só venha a ser documentado em Tucídides (JAEGER, 1968, p. 52). Por outro lado, já em Hesíodo é possível identificar sinais claros de que um novo paradigma se formava: "já no prólogo da Teogonia de Hesíodo, as Musas declaram: 'Sabemos dizer muitas coisas enganosas, semelhantes a realidades, mas também sabemos, quando o queremos, dizer coisas verídicas"” (vv. 28-31) (LIMA, 2003, p. 34).

A palavra do poeta, então, passaria aos poucos a ter reconhecido o seu caráter movediço, a ambiguidade que se crê constituinte, hoje, de toda linguagem. Seu discurso vai se tornando apenas mais um entre outros, passível de se julgar como ora falso, ora verdadeiro. É esse mesmo longo processo, intensificado entre os séculos VI e V a. C., que, segundo Snell, tornará a relação de Píndaro com os deuses bastante diferente daquela, tão mais próxima, que com eles terá mantido Safo, por exemplo (SNELL, 1962, p. 191). O tempo que os separa é o tempo em que surge a prosa, e assim a reflexão sobre o homem, os deuses e a natureza, fazendo com que a Píndaro não baste mais apenas invocar os deuses e os relatos heroicos da tradição, mas refletir e pesquisar, em meio a eles, o lugar da verdade, traço que, entre muitos outros, será distintivo de sua poesia (SNELL, 1962, p. 191). Daí que sejam de grande interesse passagens como a que segue, extraída da sua primeira "Olímpica", em que o relato mítico é suspendido para dar lugar a uma reflexão:

$[\ldots]$

Posídon, quando do puro caldeirão

o retirou Cloto, adornado de marfim no ombro brilhante.

Muitas são decerto as maravilhas; porventura a fala dos mortais excede o discurso da verdade: adornados com variegadas mentiras os mitos enganam.

[...] (PÍNDARO apud LOURENÇO, 2006, p. 97-8)

Entre a palavra e a verdade reconhece-se agora uma instância humana, a "fala dos mortais", que "excede o discurso da verdade". Entre palavra e verdade, assim, precisa haver agora a interpretação, como que para separar, do joio, o trigo. Esse será um projeto, sobretudo, da filosofia, mas Píndaro não deixa de tangenciálo em sua poesia, como vemos. Mas a sua atitude, no trecho imediatamente seguinte, é das mais curiosas. Se a beleza do discurso nos engana tantas vezes, fazendo-nos crer diante da verdade, e se pouco ou nada somos capazes de fazer para dirimir, de uma vez por todas, nossa dúvida a tal respeito, que repitam sobre os deuses os poetas senão as coisas boas, pois, ainda que falsas, serão motivo de culpa menor: 
$[\ldots]$

Mas a beleza, que fabrica para os mortais todas as coisas agradáveis, leva, ao conferir a honra, a que o incrível se torne crível

a maior parte das vezes.

Porém os dias vindouros

disso darão o mais sábio testemunho.

Fica bem ao homem dizer acerca dos deuses

Coisas belas: menor será a culpa.

[...] (PÍNDARO apud LOURENÇO, 2006, p. 98).

A solução de Píndaro para o impasse que surge, portanto, parece ser nenhuma. A verdade sobre os deuses, por um lado, misturada ao emaranhado das falas mortais, não parece mais passível de identificação, tamanho pode ser o efeito de verdade que um discurso mortal, mesmo falso, pode produzir; mas Píndaro, por outro lado, renunciando à tarefa filosófica de encontrar a verdade, conclui seu raciocínio como quem lava as mãos: condenados terminantemente à mentira humana, ou seja, a reproduzir indistintamente o excedente discursivo que engendramos nós mesmos para além da verdade, e a reproduzi-lo, eventualmente, mesmo quando nos cremos os porta-vozes dos deuses, então - diz-nos Píndaro - sigamos mentindo; apenas mintamos, no entanto, ao tê-los louvado, e não ao ter divulgado as narrativas que os difamam. A "dobra" da palavra, para usarmos a expressão de Costa Lima, parece, aqui, não apenas reconhecida em sua plenitude, mas acolhida, também, com desprendimento incomum. O que, no entanto, primeiro nos interessa: ao interpor-se entre palavra e verdade, a "dobra" inauguraria o descompasso entre ambas, tornando muito menos simples a relação entre os humanos e os deuses. Entre eles, agora, individualiza-se uma terceira instância: o labirinto da linguagem, não mais reconhecido como co-geminado à verdade.

Os pontos de contato desse longo período da história com o processo que vemos entre o renascimento e o barroco não parecem poucos. As semelhanças parecem começar na admiração, por parte da arte quinhentista, por aquilo que, segundo Tasso, terá sido "a unidade da fábula, a solidez e o verossímil, que nos poemas de Homero e de Virgílio se veem [as traduções citadas do texto de Tasso são de nossa autoria]" (TASSO, II, \$25).

Os modos pelos quais Tasso declara seu amor à verdade, à palpabilidade e aos contornos firmes do mundo homérico são vários, e se estendem ao longo dos seus três Discorsi, escritos em 1587. À medida que os lemos, no entanto, torna-se pouco a pouco claro o que chamaríamos de certa tensão implícita, que aproxima e distancia, a um só tempo, a arte de Tasso e a arte do aedo. Escolhemos apenas algumas poucas passagens-chave, de modo que possamos ver de perto em que novos termos a verdade do poema heroico é apresentada.

A veracidade dos sucessos narrados, diz Tasso, teria uma função fundamental junto aos leitores, que,

tomando-os por falsos, não consentirão tão facilmente serem conduzidos à ira, ao temor ou à compaixão; terem o espírito alegrado, entristecido, suspendido ou aprisionado; e, por fim, não presidirão aos sucessos das coisas com o interesse e o deleite com que o fariam se, aos mesmos sucessos, no todo ou em parte, tomassem por verdadeiros (TASSO, I, \4). 
Tasso, aqui, considera, hipoteticamente, uma possibilidade provavelmente inimaginável no mundo homérico: a de o público não tomar por automaticamente verdadeira a palavra do poeta. A idéia parece repetir-se no que segue:

se deve o poeta com a verdade aparente enganar os leitores, e não apenas persuadi-los de que as coisas tratadas sejam verídicas, mas apresentá-las de tal forma a seus sentidos que não as creiam ler, mas, sim, tê-las presentes diante de si, vê-las, ouvi-las, faz-se necessário instilar-lhes na alma a convicção de que são verdades; o que, com a autoridade da história, consegue-se facilmente [...] (TASSO, I, \$5).

Tasso, ao que parece, fala-nos da necessidade de se persuadir o leitor. Ao fim da mesma passagem, volta ao aspecto que vimos comentar acima: a importância de preferivelmente se adotar, por matéria do poema, fatos reais, fatos cuja veracidade é atestada pela história. Mais adiante (TASSO, III, \$16), falará na plasticidade alcançada por Dante em certas descrições - às quais poderíamos somar como exemplo as batalhas de Homero ou as tempestades de Camões —: aí estará um caso concreto do que quer dizer com "ter diante de si”, "ver" e "ouvir" os sucessos narrados. Num e noutro caso, o intuito subjacente seria o mesmo: a persuasão do leitor, o "instilar-lhe na alma a convicção" sobre a verdade do narrado.

O modo como Tasso lida com a necessidade, por ele admitida, de que se deixe acolher no poema heróico o maravilhoso é um outro aspecto revelador, do qual não poderíamos prescindir:

de pouco deleite, é bem verdade, será o poema que não traga em si aquelas maravilhas que, não só o espírito dos incultos, mas também o dos judiciosos, têm o poder de mover: falo dos anéis, dos escudos encantados, dos corcéis alados, dos navios que se convertem em ninfas, dos espectros que se interpõem entre as milícias e outras coisas do gênero; das quais, quase como de temperos, deve o escritor judicioso lançar mão para condimentar seu poema (TASSO, I, \6).

É uma asserção que parece em contraste indisfarçável com o princípio "notissimo" dos Discorsi, segundo o qual

A poesia, em sua essência, não é nada além de imitação, e isso não se pode pôr em dúvida; a imitação não pode prescindir do verossímil, uma vez que imitar é o mesmo que fazer igual; porção alguma da poesia pode se separar do verossímil; e, por fim, não é o verossímil uma das condições a se exigir da poesia para sua maior beleza e ornamento, mas é, antes, próprio e intrínseco à sua essência, e, em cada porção dela, mais que qualquer coisa necessário (TASSO, I, \7).

Mas a solução para o impasse entre verdade e maravilha, a fórmula para "que uma à outra não ceda, mas que seja uma pela outra temperada" (TASSO, I, §7), sem prejuízo para qualquer das partes, não deixa de ser encontrada por Tasso: 
ela estaria no maravilhoso cristão, que, por uma contradição apenas aparente, seria, sim, verossímil, já que se trata de uma "religião tida por verdadeira por nós" (TASSO, I, 『9), assim como terá sido verdadeiro para os gregos, por exemplo, o deus Apolo. Anjos, demônios e milagres, portanto, estariam em plenas condições de prover todo o maravilhoso necessário, com a vantagem de não perturbar a verdade do poema - exatamente como na suposta recepção do poema homérico.

Essas passagens, pensamos, serão já suficientes para trazer à tona os dois pontos para nós essenciais. Em primeiro lugar, a sensibilidade de Tasso ao compreender que espécie de vínculo pode ter unido ouvintes e aedo no momento da recepção: a condição de verdade de que se investiria o discurso do aedo em plena récita terá sido um combustível indispensável ao prazer de ouvi-lo, ideia essa que não entraria em desacordo, como vimos, com a pesquisa moderna a respeito da verdade no mundo homérico; em segundo lugar, a clareza com que aquilo que terá sido a verdade em Homero parece se deixar substituir, sutilmente, pelo que seria antes um efeito de verdade em Tasso: é que a verdade tassiana, nas passagens citadas, aparece como um resultado a se obter graças ao poder persuasivo da composição; a sua verdade ganha vida, antes de tudo, por meio dos poderes de uma retórica calculada, minuciosamnete estruturada em função de um propósito. E, mesmo quando Tasso concede importância, por exemplo, ao testemunho da história, solicitando, assim, a adequação do poema a uma realidade ontológica anterior, a uma verdade substancial para além do desempenho retórico, é inegável a relativização que termina por lhe impor. É o que fica patente, por exemplo, em sua opinião sobre Lucano: de nada terá servido a este o ater-se tanto aos particulares históricos, enquanto relegasse a segundo plano, como fez, o efeito de verdade que o bom manuseio retórico do meramente verossímil lhe garantiria:

E se não creio Lucano um poeta, não me move a tanto a razão que a alguns outros, a essa opinião, induz, isto é, a de que não seja poeta porque narra acontecimentos verdadeiros. Isso, apenas, não basta: poeta ele não é, na verdade, porque se obriga de tal maneira à verdade dos particulares que não tem respeito ao verossímil em sentido amplo; e porque narra as coisas tal como ocorreram, não cuidando de imitá-las segundo deveriam haver ocorrido (TASSO, II, $\left.\int 4\right)$.

O erro de Lucano, assim, faria dele um contra-exemplo em relação a um dos primeiros conselhos de Tasso:

antes de tudo deve o poeta verificar se, na matéria de que pretende tratar, há qualquer acontecimento que, ocorrendo de outra maneira, pudesse proporcionar maior deleite, seja pela maior verossimilhança, pela maior maravilha ou qualquer outra causa; e, a todos os sucessos que assim encontrar, ou seja, aos sucessos que talvez lhe pudessem servir melhor se outramente ocorridos, os mude e re-mude a seu bel-prazer, sem respeito algum à verdade e à história, e reduza os acidentes de cada coisa à forma que julgue melhor, à verdade alterada fazendo o inventado acompanhar (TASSO, I, \$1). 
Daí que, por fim, talvez se pudesse depreender, sem quaisquer prejuízos: a verdade que emana do poema, que em Homero terá sido uma dádiva de sua cultura, será, em Tasso, o resultado de um ato consciente de mestria retórica.

A questão, no entanto, talvez esteja longe de ser tão pacífica e autoevidente para o próprio Tasso - ao menos se tomamos os Discorsi por referência. Embora o próprio testemunho da história, em todo o caso, não deixe de constituir a nossos olhos uma espécie de resíduo, serão ainda outras passagens, a exemplo da que segue abaixo, que nos servirão de índice inconteste de que a radicação da poesia numa verdade maior que habita o mundo, uma verdade para além do desempenho retórico, não pôde, simplesmente, ser friamente posta de lado como que a fazer do poeta, reconhecidamente, o rétor absoluto de um mundo esvaziado. Ordem do mundo e ordem do poema parecem querer-se, aqui, novamente irmanadas, mutuamente implicadas:

assim como neste admirável magistério de Deus, que mundo se chama, vê-se o céu, esparso ou diverso pela tamanha variedade das estrelas; e, descendo, mãos dadas um ao outro, o mar e os ares, que os peixes e aves enchem; e a terra, que abriga os animais, os mansos e os ferozes, e os rios e lagos, e as fontes e planícies, e o prado; aqui, o fruto e as flores; ali, granizo e neve; aqui, as culturas e as aldeias; ali, o horror e a solidão; e, apesar disso, apenas um é o mundo que tantas coisas, e assim diversas, em si mesmo encerra; apenas uma é a forma e a essência sua; apenas um é o modo segundo o qual suas partes, em discórdia concorde, convergem, coligam-se; e nada falta a esse mundo, e nem, tampouco, lhe sobra algo dispensável: assim julgo, semelhantemente, que o bom poeta (que não por outra coisa é dito divino, senão porque, assemelhando-se ao supremo artífice em seu proceder, vem a compartilhar de sua divindade) possa dar forma a um poema em que, quase como num pequeno mundo, se possam ler, aqui, a ordenação de exércitos; aqui, batalhas terrestres e navais; aqui, a expurgação de uma cidade, escaramuças e duelos; aqui, torneios; aqui, descrições de fome e sede; aqui, tempestades; aqui, incêndios; aqui, prodígios; e, ali, reúnam-se concílios celestes e infernais; e, ali, se assista a sedições; ali, a discórdias; ali, a erros; ali, a venturas; ali, a encantos; ali, a obras de crueldade, audácia, cortesia ou generosidade; ali, a episódios amorosos, ora felizes, ora não, ora alegres, ora piedosos; ainda que, em todo caso, seja apenas um o poema com tal variedade de matérias; uma a forma e a fábula suas; e que todas essas coisas sejam compostas de forma que uma reflita noutra, que uma a outra corresponda, que uma da outra, necessariamente, dependa, sem dispensar o verossímil; de forma que uma só parte se excluindo, ou tendo-se alterado seu lugar, o todo ceda arruinado (TASSO, II, \$26).

O tom elevado, a escolha vocabular e o ritmo da passagem nos fazem lembrar a contaminação pontual da prosa pré-socrática grega pela linguagem dos hinos religiosos: não por acaso, o fenômeno tem lugar exatamente nas passagens em que, segundo Jaeger, se trata da arkhé, ou seja, do elemento que os filósofos tomem pelo princípio fundamental das coisas (JAEGER, 1968, p. 71). Tasso, aqui, 
parece bordejar exatamente o que seria o centro de sua visão de mundo - centro a um só tempo lógico, filosófico, religioso, ético, estético e, diríamos ainda, afetivo.

Contrapondo-se o belo hino ao mundo que aí compõe e a sensibilidade retórica que demonstra nas passagens anteriores, cremos poder supor a existência, na visão de mundo de Tasso, de uma tensão implícita, talvez insolúvel: de um lado, o amor à substancialidade do mundo e da história; do outro, a possibilidade entrevista de que a mesma substancialidade não passe de uma ilusão produzida no seio da língua, no seio da cultura: pois, assim como a Tasso será dado infligir a ilusão retórica da verdade, abrir-se-ia o precedente para que lhe fosse dado sofrêla. O seu hino ao mundo, então, somado à consciência retórica, assim nos permitiria resumir: Tasso tomou posse da verdade retórica, mas isso é pouco; continua a sonhar com o porto inabalável da verdade homérica, em que a fonte de onde brota o poema está no seio das coisas.

Estaríamos, assim, ao comparar Tasso e Homero, diante de duas situações culturais bastante díspares, em que pese a coincidência dos contornos sólidos que, em sua arte, ambos conferem ao mundo. A situação cultural de Tasso talvez encontre descrição apropriada num texto de época bem posterior, o "Über naive und sentimentalische Dichtung", de Schiller, escrito em 1795 (SCHILLER, [s./d.]). Em um dos passos de sua argumentação, o que Schiller faz é, precisamente, contrapor à idade homérica as idades posteriores, em que certa unidade fundamental se terá perdido:

Enquanto o homem é natureza pura (não natureza crua, entendase), apresenta-se como totalidade indivisível dos sentidos e como todo harmônico. Sentidos e razão, faculdades adquiridas e faculdades inatas, em seus atos, ainda não se distinguem, nem, muito menos, contrapõem-se. Suas sensações não são o jogo informe do acaso; seus pensamentos, não o jogo oco da imaginação; sob o signo do necessário regem-se aquelas, e sob o da realidade regem-se estes. Tão logo adentre o homem um estado de cultura, e nele pouse a mão o artificial, aquela harmonia dos sentidos é suspendida [...]. A harmonia entre sensação e pensamento, que no primeiro estado realmente existia, existe agora apenas idealmente; ela não mais se encontra dentro dele, mas, sim, fora dele, como uma idéia que precisa se realizar e não como um fato de sua existência [as traduções citadas do texto de Schiller são de nossa autoria] (SCHILLER, [s./d.], p. 106).

A verdade homérica, assim, signo de um mundo sempre em uníssono com a cultura, no tempo em que era uma realidade vivida, não teria sido passível de ser individuada como conceito, ou seja: o próprio fato do seu estabelecimento, por Tasso, como meta maior de sua criação poética, fato que pressupõe a sua individuação como conceito, já seria suficiente, segundo a argumentação de Schiller, para que se atestasse o abismo que há entre os dois mundos culturais. A verdade homérica, no caso, para Tasso, seria exatamente como a "natureza" para Schiller: "na medida em que a natureza, pouco a pouco, começa a desaparecer da vida humana como experiência e como sujeito (que age e percebe), vemo-la surgir na poesia como idéia e objeto" (SCHILLER, [s./d.], p. 102). Ou, ainda mais concisamente: "eles [os antigos] percebiam naturalmente; nós percebemos o natural [grifo nosso]" (SCHILLER, [s./d.], p. 102). Em outras palavras: o surgimento da 
"dobra" da palavra, pondo fim à antiga razão de um para um entre cultura humana e mundo autônomo, não seria, simplesmente, o ponto a partir do qual a verdade homérica se tornará passado, mas o ponto, sempre segundo Schiller, a partir do qual ela se ausentará do plano da vivência efetiva para se tornar, na consciência de sujeitos já cientes da queda, não mais que uma ideia: é aí, precisamente, e provavelmente a contragosto, que vai se encontrar na história o nosso Tasso.

O texto de Schiller, junto ao de Tasso, vem nos conceder ainda outro testemunho. Se conhecíamos já, de um lado, a inveja da renascença em relação à verdade homérica, temos agora, do outro, a inveja romântica em relação à naturez̧a homérica. Serão ambas, na verdade, apenas dois ângulos diferentes, ao que parece, diante de um mesmo quadro cultural: dois nomes, matizados em seu lugar de origem, para o mesmo fascínio renitente que a suposta unidade homérica entre cultura e mundo, unidade perdida, virá exercendo sobre as diferentes épocas.

Já a Tasso, portanto, estaria vetado ser Homero. Seu vislumbre do mundo retórico, e a consequente relativização das verdades, por outro lado, embora suficiente para lhe obstar o ingresso pleno na Idade de Ouro, seria ainda relativamente incipiente: muito distante, por exemplo, do reconhecimento expresso que vimos em Píndaro do que é admitir o abismo retórico em sua total extensão. Alguém estará disposto a, tão desinibidamente quanto o poeta grego, anunciar na renascença a condição mortal de toda fala? Não parece ter sido esse, claro está, o caso de Tasso, ainda que nos já tenha apresentado em seus Discorsi, de modo velado, e mesmo que sem pretensões à filosofia, as peças que irão compor mais tarde uma crise indisfarçável da transcendência.

Se há algum sentido nesse diagnóstico, podemos estar diante de um segundo coração do que será chamado, mais adiante, o barroco; um segundo coração para além da tensão, frisada sempre, entre o divino e o terrenal, qual seja: a desestabilização do mundo ontológico pelo mundo retórico. Se esta, no campo do pensamento sobre a arte, pode ter sido fonte de tensão, que dirá de sua presença no campo da hermenêutica religiosa? Chegamos, finalmente, ao texto de Vieira.

Os trechos que seguem, essenciais para nós, são da parte IX do Sermão da Sexagésima:

Sabeis, Cristãos, a causa por que se faz hoje tão pouco fruto com tantas pregações? É porque as palavras dos pregadores são palavras, mas não são palavras de Deus. [...].

Mas dir-me-eis: Padre, os pregadores de hoje não pregam o Evangelho, não pregam das Sagradas Escrituras? Pois como não pregam a palavra de Deus? Esse é o mal. Pregam palavras de Deus, mas não pregam a palavra de Deus. "O que tem a minha palavra anuncie a minha palavra verdadeiramente" (Jr 23,28), disse Deus por Jeremias. As palavras de Deus pregadas no sentido em que Deus as disse são palavras de Deus; mas pregadas no sentido que nós queremos não são palavras de Deus, antes podem ser palavras do Demônio. [...] Cristo defendeu-se do Diabo com a Escritura, e o Diabo tentou Cristo com a escritura (VIEIRA, 2008, p. 27-8).

Um único texto, diz Vieira, mas dois sentidos: um, divino; o outro, diabólico. Dois parágrafos à frente, o exemplo concreto que atesta essa possibilidade, de modo esclarecedor. A passagem vai transcrita sem cortes: 
Estava Cristo acusado diante de Pilatos, e diz o evangelista S. Mateus que por fim vieram duas testemunhas: "Finalmente apareceram duas falsas testemunhas" (Mt 26,60). Estas testemunhas referiram que ouviram dizer a Cristo que, se os Judeus destruíssem o templo, ele o tornaria a reedificar em três dias. Se lermos o evangelista S. João, acharemos que Cristo verdadeiramente tinha dito as palavras referidas. Pois se Cristo tinha dito que havia de reedificar o templo dentro de três dias, e isso mesmo é o que referiram as testemunhas, como lhes chama o evangelista testemunhas falsas: "Duas falsas testemunhas?" $\mathrm{O}$ mesmo S. João deu a razão: "Ele falava do templo de seu corpo" (Jo 2,21). Quando Cristo disse que em três dias reedificaria o templo, falava o Senhor do templo místico de seu corpo, o qual os Judeus destruíram pela morte, e o Senhor o reedificou pela ressurreição; e como Cristo falava do templo místico e as testemunhas o referiram ao templo material de Jerusalém, ainda que as palavras eram verdadeiras, as testemunhas eram falsas. Eram falsas, porque Cristo as dissera em um sentido, e eles as referiram em outro; e referir as palavras de Deus em diferente sentido do que foram ditas é levantar falso testemunho a Deus, é levantar falso testemunho às Escrituras. Ah, Senhor, quantos falsos testemunhos vos levantam! Quantas vezes ouço dizer que dizeis o que nunca dissestes! Quantas vezes ouço dizer que são palavras vossas o que são imaginações minhas, que me não quero excluir deste número! (VIEIRA, 2008, p. 29).

Tais trechos dão testemunho do quão aguda era a consciência retórica seiscentista. Vieira diz aqui, quase dois mil anos depois, algo muito próximo do que havia dito Píndaro na passagem que citamos da primeira "Olímpica". As quatro últimas linhas do trecho trazem de novo à tona o emaranhado labiríntico das vozes mortais, em meio às quais, em algum lugar, repousará perdido o fio das imaginações divinas, o fio do testemunho verdadeiro. Vieira, ao que parece, pisa o beiral daquele mesmo e amplo abismo retórico, e aí talvez chegue perto - talvez perto demais - do limiar de sua própria ruína, expondo tão claramente o estatuto problemático da linguagem. "Quantas vezes ouço dizer que são palavras vossas, o que são imaginações minhas, que me não quero excluir deste número!”: embora censure na passagem o falso testemunho, Vieira não deixa de sugerir sua própria condição de, apenas, não mais que um rétor entre outros, passível também do engano. Ou, para ficarmos com Píndaro: Vieira não se exime de assumir sua própria condição de "mortal", passível também do "excesso". A passagem parece abrir o precedente para uma pergunta desafiante: "- Como saberá em absoluta certeza o pregador, que nos exorta, se a sua palavra é a de Deus?”. Píndaro terá podido, diante dela, lavar as mãos, como vimos, admitindo sua frágil condição "mortal" e levando adiante, abertamente e sem rubores, o mentir humano; mas que terá podido dizer um sermonista católico em meio à contra-reforma, cujo ofício era arrebanhar o maior número possível de mortais, digamos, para dentro da Verdade? Voltaremos a esse ponto.

O exemplo de Vieira, assim, traz um particular trágico, desesperador: "ainda que as palavras eram verdadeiras, as testemunhas eram falsas". Porque — aí nos ensina — os sentidos são móveis por sob a efígie estanque das palavras. Essa 
aguda consciência do jogo, da instabilidade inerente dos construtos de linguagem - consciência devedora também da aplicação da hermenêutica, propugnada por humanistas como Erasmo de Roterdã, aos textos religiosos -, essa aguda consciência a respeito da "dobra" da palavra terminará, como talvez fosse de se esperar, contribuindo para que se desestabilizem, para que se tornem cada vez menos confiáveis, as estruturas assentes do mundo. Quando nem mesmo a palavra divina é una, porque é palavra, podendo abrigar sentidos múltiplos, o que poderá restar das grandes certezas? A instabilidade, como no exemplo bíblico evocado no Sermão, estará agora sempre à espreita.

Nada mais sintomático, nesse sentido, do que a exclamação, tipicamente neoclássica, de Verney, citado por Ávila:

"Que seria do Mundo Retórico, se todos os homens um dia abrissem os olbos?" A exclamação é de Verney e nela percebemos implícita a alusão do pedagogo português ao papel negativo da retórica tal como ele a via na cultura de seu tempo, como fator de encobrimento da verdade e, portanto, de deformação da idéia do homem sobre a realidade do mundo (ÁVILA, 1971, p. 72).

Falamos, de fato, ao início do texto, no que seria uma grande incursão barroca nas virtualidades da língua: a manipulação das instabilidades linguísticas em direção ao ilusório. Dissemos que essa incursão traria à tona, com a sobreposição vertiginosa de metáforas, sons, texturas e jogo lógico, a mobilidade inapreensível de formas ilusórias a que o discurso, em verso ou prosa, pode se reduzir. Se a retórica de Tasso tinha por meta maior um único efeito - o efeito de verdade - , a retórica do barroco, como que esquecida de toda diretriz externa, parece multiplicar sem limite as suas metas — os seus efeitos —, entregando-se às mais livres pulsões e associações, ao fluxo livre da harmonia prosódica, das imagens oníricas e dos quebra-cabeças lógico-sintáticos. É aqui que a imagem de soterramento do mundo ontológico pelo mundo retórico ganha seu sentido pleno de ser, uma vez que é a pluralidade móvel de elementos do mundo retórico que vemos se erigir em índice inconteste de sua presença: descontrolam-se, assim, as formas poéticas, afogando os encadeamentos da fábula ou do raciocínio; e encobre-se assim, igualmente, a palavra de Deus, eclipsada pela inflação sensorial, pela hiperestesia hipnótica que toma a voz dos sermonistas.

Diante de tamanha instabilidade, Verney toma partido, pura e simplesmente, do mundo, à revelia das fragilidades incontornáveis — ao menos se trazemos a efeito a mobilidade apresentada por Vieira, e explorada pela poética barroca - de tudo aquilo que somos capazes de enunciar sobre ele. A Verney, ao que parece, é dado temer, com muito maior decisão do que fora dado a Tasso, o mundo retórico, pois é sem qualquer traço de hesitação que o vemos se aferrar expressamente ao mundo sensível, à sua aparente solidez ontológica.

Vieira, em sua queixa aos sermonistas em atividade, poderia parecer compartilhar, à primeira vista, da posição de Verney. Por outro lado, no que diz respeito ao autor do Sermão — e aqui voltamos a ele —, parecer-nos-ia uma incoerência identificar em Tasso a tensão que identificamos e, quanto a Vieira, simplesmente ignorar a tão mais aguda e sutil consciência do jogo retórico, demonstrada mais acima; parecer-nos-ia uma incoerência crê-lo convocar diante desta, sem mais, como um deus ex machina, a substancialidade impenetrável do mundo, como Verney, dirimindo todas as dúvidas. E seria uma incoerência, 
sobretudo, porque o Sermão continua, linha a linha, afirmando-se fundamentalmente como obra de rétor. É o que demonstra também o próprio Ávila, por exemplo, em suas análises.

A unidade essencial do Sermão estaria adornada, malgrado as críticas do próprio Vieira, com artifícios retóricos típicos da época; ela seria apenas impedida - eis a grande diferença - de "cair numa propensão para a infinitude e para o impreciso, numa vertigem aliás comum na formatividade barroca” (ÁVILA, 1971, p. 66). Vejamos um exemplo dessa espécie de equilíbrio, e de como ele funciona. Ávila fala de um "processo de recargamento" da linguagem, atomizada em "imagens-síntese":

"Porque como os Apóstolos iam pregar a todas as nações do mundo, muitas delas bárbaras e incultas, haviam de achar homens homens, haviam de achar homens brutos, haviam de achar homens troncos, haviam de achar homens pedras" (p. 3/4). A imagem contrai-se de tal maneira à sua absoluta essencialidade substantiva, que pode ser apreendida quase visualmente [...]. Semelhante artifício de extrema objetivação, concreção da linguagem, que o prosador foi buscar por certo ao campo mais livre das construções poéticas, mostra como no sermão vieiriano o ordo artificialis, ao invés de enfraquecer ou suspender durante a pausa de relaxação do auditório a carga persuasória do discurso, propende ao contrário a reforçar-lhe a credibilidade (ÁVILA, 1971, p. 69).

As imagens de Vieira funcionariam como centros coagulantes da mensagem. Seriam repositórios em que ela se encontra na mais alta pressão, tanto para a conveniência da memória quanto para o aprazimento dos sentidos. São os embaixadores do Sermão em nossa memória. São os relevos que saltam da superfície lisa (ÁVILA, 1971, p. 68).

A implicação maior do que aí se constata nos parece levar, em certo sentido, de volta às considerações sobre Tasso. O caso é que a clareza do sermão vieiriano — ou sua "credibilidade" —, qualidade que ele mesmo vem exigir dos seus irmãos de ofício, não será uma virtude a se medir, fundamentalmente, segundo o nível de adequação do discurso a uma realidade ontológica anterior, ou, no caso, de sua real adequação ao "testemunho" verdadeiro - ao repertório das “imaginações” inequívocas de Deus, e não dos mortais. A questão, na verdade, diz respeito ao engenho poético, ao desempenho retórico. Há motivos adicionais para assim pensarmos, e que afastam Vieira de modo inequívoco do ponto de vista de Verney; eles parecem se esconder numa série de implicações, implicações que ajudarão a aprofundar o nosso juízo sobre ser o Sermão, fundamentalmente, obra de um rétor.

Manter em termos ontológicos o tratamento da credibilidade ou clareza da composição, movimento apenas esboçado por Vieira em nosso trecho, mas não aprofundado, demandaria do sermonista que o próprio se admitisse, expressamente, e o demonstrasse inequivocamente por meio do discurso, como detentor inconteste do conhecimento teológico último, ou seja, da plenitude do conhecimento acerca da palavra divina: somente assim estaria em poder de evidenciar, de modo convincente, a diferença que haveria, em termos outros para além do mero desempenho retórico, entre seus irmãos de ofício e ele mesmo. $\mathrm{O}$ Sermão, nesses termos, teria lhe saído muito menos uma diatribe contra um estilo 
do que uma bem mais grave diatribe contra sermonistas heréticos: sermonistas que então divergiriam, comprovadamente, do ensinamento divino. Seríamos obrigados, aí, a substituir a discussão retórica por uma discussão teológica. Em outras palavras: esse novo discurso hipotético, sob a pena de resultar inócuo, precisaria romper com o silêncio do Sermão acerca, justamente, da questão irrespondível: "- Como saberá em absoluta certeza o pregador, que nos exorta, se a sua palavra é a de Deus?". O caminho de Vieira ao compor o Sermão, seja por que motivo for, não parece ter sido esse.

Por outro lado, ainda que Vieira, expressamente, reputasse tal conhecimento como dado de modo inequívoco, como passível de demonstração inequívoca via discurso - por si só um paradoxo, segundo faz crer a visão barroca -, pode ser que a adequação hipotética do seu discurso a esse conhecimento, se seguimos com Tasso, de nada viesse a servir ao sermonista em termos de força persuasiva, semelhantemente ao que terá ocorrido com Lucano em relação à história. Como vimos, Lucano ter-se-ia atido, segundo Tasso, aos particulares históricos verdadeiros, mas teria aberto mão, sofrivelmente, dos artifícios que lhe renderiam um efeito de verdade realmente aliciante; assim, ainda que o nosso sermonista se ativesse minuciosamente aos particulares de sua verdade teológica, nada disso lhe garantiria, igualmente, o aliciante efeito de clareza que, como no Sermão, um bom manuseio do ordo artificialis pode pôr em cena.

Em outras palavras, o que tudo isso quer dizer: o "não" de Vieira a seus irmãos de ofício não poderá ser o mesmo "não" que diz Verney ao mundo retórico, tomando por referência uma verdade extradiscursiva e segura acerca do mundo. Vieira não recorre, como recurso último, ao deus ex machina. A clareza vieiriana, assunto central do Sermão, e motivo da divergência do autor frente à sermonística da época, é tangenciada noutros termos, sendo uma qualidade do que haja em Vieira de excelente rétor, e muito pouco do que nele haja de bom teólogo. Sua clareza, como a verdade em Tasso, é obra de artífice. E é o trabalho do artífice o que está em discussão no Sermão. Ao se aprofundar na senda teológica, sobre a qual silencia, Vieira talvez consumasse não mais que o suicídio de seu ofício: o reconhecimento cabal, tão cabal quanto o de Píndaro, de que seu próprio discurso não seria nada além da dóxa, e de que não poderia saber, em absoluto, em que lugar estará escondida a palavra de Deus - perdida, talvez para sempre, depois de reconhecida a "dobra" da palavra. Vieira, assim, terá pisado o beiral do amplo abismo retórico, como referimos, mas, depois de usar suas potencialidades em favor próprio, terá dado meia-volta, guardando para si as conclusões mais amplas sobre o que vira, ao contrário do poeta grego. Melhor terá sido prevenir, sobretudo se o tempo era de crise, a invasão do racional em terrenos que, salvo engano, melhor se preservam se reservados, apenas, à fé.

Ainda quanto à natureza retórica da clareza vieiriana, talvez possamos nos apropriar de uma imagem bem conhecida do Sermão:

As palavras são as estrelas, os sermões são a composição, a ordem, a harmonia e o curso delas. Vede como diz o estilo de pregar no céu [...] Ordenado, mas como as estrelas [...] Todas as estrelas estão por sua ordem; mas é ordem que faz influência, não é ordem que faça lavor. Não fez Deus o céu em xadrez de estrelas, como os pregadores fazem o sermão em xadrez de palavras. Se de uma parte está branco, da outra há de estar negro; se de uma parte está dia, da outra há de estar noite; se de uma parte dizem luz, da outra hão-de 
dizer sombra; se de uma parte dizem desceu, da outra hão-de dizer subiu. Basta que não havemos de ver num sermão duas palavras em paz? Todas hão-de estar sempre em fronteira com o seu contrário? Aprendamos do céu o estilo da disposição, e também das palavras [...] (VIEIRA, 2008, p. 22).

O arranjo de tais estrelas, estrelas verbais, seria imprevisto: cada um deles é somente um ante a infinitude opressora de tantos outros mais, igualmente passíveis de se desenhar, com igual poder de luz, na virtualidade de um céu inteiro e escuro, um céu que não exibe gabaritos fixos, que não exibe estruturações prédadas, reconhecíveis como originárias. A ordem aparentemente inconteste que vislumbramos em determinados arranjos em oposição a outros será obra antes do engenho humano que de sua correspondência para com a verdade do mundo, dos deuses ou de Deus. O suposto gabarito fixo com que sonhamos céu acima (e também Tasso? Píndaro? Vieira?), para além do tecido insubsistente das estrelas, será objeto de discussão perene, ou se resolverá na fé. Não se resolverá, ao que tudo indica, no discurso.

Essa, que parece ser a condição da língua barroca, parece ser também a do mundo moderno. Enquanto cai sob suspeição toda e qualquer possibilidade de legitimação ontológica dos discursos, e enquanto é refinada a nossa sensibilidade frente às forças da retórica, frente às verdades parciais e situadas que, diariamente, produzimos com os materiais da contingência, parecemos repetir a história: oscilamos, assim, entre o desprendimento pragmático de Píndaro e uma espécie cética, porém vigilante, de espera. Essas parecem ser, por exemplo, as duas atitudes que Richard Rorty atribui, respectivamente, a Dewey e a Heidegger, ao comparar o contributo dos dois à filosofia do século XX:

É quando Dewey vê filosofias - o pensamento de Platão, Tomás de Aquino, Hegel - do mesmo modo como um engenheiro vê regiões da Terra ricas em minério que Heidegger se constrange. Tratar o pensamento de Hegel como Weltanschaunng ["visão de mundo"] é vê-lo antes como objeto de exploração do que como ensejo de uma possível revelação. É tratar as filosofias como um meio de melhoria da vida humana [tradução nossa] (RORTY, 2003, p. 50).

Mais adiante, completa:

Um modo de trazer à tona a diferença [entre os dois filósofos] é dizer que Dewey considera a filosofia - como disciplina ou mesmo como atividade humana digna de apreço — obsoleta. Heidegger, por outro lado, considera a filosofia - o Pensamento, contraposto à ontologia - algo a ser resgatado, muito embora a forma que venha a assumir, em nosso mundo obscurecido, seja ainda invisível [tradução nossa] (RORTY, 2003, p. 52).

Seriam ainda, igualmente, as mesmas atitudes que cremos reconhecer, respectivamente, no eu lírico de "A máquina do mundo", de Carlos Drummond de Andrade (em Claro enigma), e no eu lírico do mais recente A máquina do mundo repensada, de Haroldo de Campos: de um lado, o desinteresse convicto pelo que 
extrapole o mundo humano; de outro, a perquirição continuada em torno do improvável. Em qualquer dos casos - Píndaro, Vieira, Dewey, Heidegger, Drummond ou Campos — , respostas não há: o que há é a variação dos ânimos ante a impassibilidade constatada do mundo, dos deuses ou de Deus, enquanto a escavação prossegue em meio aos signos.

A consciência nascente do jogo, por fim, que testemunhamos em Tasso e em Vieira, seria o terceiro termo na raiz barroca, interpondo-se entre o sujeito e a figuração de centros fixos do real. Para além da eternidade divina e da temporalidade terrenal em conflito, veríamos surgir no horizonte o labirinto móvel, insolúvel, da linguagem entregue a si mesma: ameaça contra todos os nossos sonhos substantivos. De que outra forma se permitiria a dança insubsistente de adornos, tão própria do barroco?

\section{REFERÊNCIAS BIBLIOGRÁFICAS}

ÁVILA, Afonso. O lúdico e as projeções do mundo barroco. São Paulo: Perspectiva, 1971. JAEGER, Werner. "Die Theologie der milesischen Naturphilosophen". In GADAMER, H.-G. (org.). Um die Begriffswelt der Vorsokratiker. Darmstadt: Wissenschaftliche Buchgesellschaft, 1968.

LIMA, Luiz Costa. Mimesis e modernidade: formas das sombras. 2. ed. São Paulo: Paz e Terra, 2003.

LOURENÇO, Frederico. (org.) Poesia grega: de Álcman a Teócrito. Trad. Frederico Lourenço. Lisboa: Cotovia, 2006.

RORTY, Richard. "Overcoming the tradition: Heidegger and Dewey". In: RORTY, Richard. Consequences of pragmatism. Minneapolis: University of Minnesota Press, 2003.

SCHILLER, Friedrich. "Über naive und sentimentalische Dichtung". In: Sämtliche Werke. Vol. XII. Leipzig: Reclam, [s./d.].

SNELL, Bruno. "Nachwort”. In: Pindar. Siegeslieder. Frankfurt am Main, Hamburg: Fischer Bücherei, 1962.

TASSO, Torquato. Discorsi dell'arte poetica ed in particolare sopra il poema eroico. [online] Disponível na Internet via WWW. URL: http://www.classicitaliani.it/index082.htm. Último acesso em 20 de março de 2007.

VIEIRA, António. Sermões. Vol. I. São Paulo: Edições Loyola, 2008. 